\title{
Energy Concept Understanding of High School Students: A Cross-grade Study
}

\author{
Zeynep Başkan Takaoğlu \\ School of Health, Gümüşhane University, Turkey
}

Copyright(C2018 by authors, all rights reserved. Authors agree that this article remains permanently open access under the terms of the Creative Commons Attribution License 4.0 International License

\begin{abstract}
Energy is a difficult concept to be understood by students of all levels. Thus, the aim of the study is to determine how high school students at different levels perceive the energy and related concepts. In line with this purpose, 173 students in total of which 57 ones of the 9 th grade, 94 ones of the 10th grade and 22 ones of the 11 th grade participated in the study in which developmental research method of descriptive research design has been conducted. Four open-ended questions about energy and related concepts have been asked to the students in the study. As a result of the study, it is concluded that the students use energy instead of work, power, repulsion and pulling concepts and they consider energy as a feature specific to living creatures and moving situations. The potential and kinetic energy types are most expressed ones. The students frequently give examples from renewable and non-renewable energy types and they classify them accordingly. It is also concluded that they don't have enough information about conservation of energy. It is thought that this misconception among the students emerges because energy and related concepts are taught them disconnected in different lessons of different disciplines and they do not understand preconceptions about energy and related notions. It is considered that the concept networks, concept maps, and conceptual change texts will help to relate energy concepts in students' minds.
\end{abstract}

Keywords Cross-grade, Energy Concepts, Conceptual Development

\section{Introduction}

The learning of different concepts under the influence of being out of school or the environment constitutes the basis of learning. Individuals come to the educational institutions with some knowledge that they have created in their preliminary experiences and add additional knowledge in the course of their learning [1, 2, 3, 4]. The acquired knowledge before the school period is significant in students' learning [5]. As a result of learning concepts in schools, while some old knowledge overlaps with scientific knowledge, some do not do so. However, it is difficult to correct misconceptions and to enable to use knowledge overlapping with scientific knowledge instead of it [6]. An imbalance appears because of existing knowledge in individual's mind and thus a contradiction emerges [7]. As a result, it is known that current knowledge can sometimes lead to some misconceptions while learning new information [8, 9]. Ultimately, new knowledge learned in mind can also be shaped to include misconceptions. The wrong knowledge learned in some cases continues throughout the life of the individual and, consequently, the misconceptions persist even at university level studies [10, $11,12,13]$. Accordingly, it is known that it is very hard to change the misconceptions even at the end of effective teaching [14]. The first study to be done to change this knowledge aims to determine what misconceptions exist and to suggest solutions to it.

Many subjects in the physics consist of daily life and interdisciplinary situations [12]. One of these topics is energy. Energy is a multidisciplinary topic covering interaction of physics, chemistry and biology $[1,15]$. On the other hand, teaching this topic disconnectedly in each branch causes some misconceptions [16]. Furthermore, individuals have difficulties in learning the energy and related concepts from preschools to university and even in their daily life. In everyday life, the energy is used in a manner incompatible with scientific facts; for example, when an individual is tired, $\mathrm{s} /$ he says that $\mathrm{s} / \mathrm{he}$ is run out of energy or when $\mathrm{s} /$ he eats, $\mathrm{s} /$ he says $\mathrm{s} / \mathrm{he}$ is energetic [17]. These concepts used in daily life do not cover the energy definition in science concepts [5]. Besides, learning energy concept during different topics of physic lesson can be expressed as another reason of misconceptions. Because the energy and related concepts in physic lesson are taught disconnectedly [4]. Lastly, the energy is an abstract concept which can be considered as one of reasons challenging learning process [17]. It is because the content is complex and difficult to learn difficulties in the development of the energy concept in the minds of 
individuals and the concept misconceptions are increasing $[1,10]$. The content of energy topic contains many misconceptions depending on mentioned hardships.

It is known that even though the concept of energy started to be taught in primary school and this concept exists in daily life and different lessons, it creates many misconceptions $[10,11,12,13]$. When the literature is examined, different misconceptions about the concept of energy are emerging among students at different levels from primary school to university level $[3,5,17,18,19$, 20]. This is a result of that the energy concept has various difficulties at different levels of learning [11, 21]. The emergence of misconceptions at all levels as a result of the studies reveals the difficulty of correcting the misconceptions of energy concepts.

Although it is seen that a part of misconceptions of students has changed in studies conducted taking into consideration developmental levels, similar misconceptions generally emerge in different topics [22, 23]. While such studies reveal the difficulties of learning the concept, they also provide information about the development of the misconceptions. When the studies on different levels of learning related to the concept of energy are examined, it seems that they are at primary school $[4,5$, $36]$ or at university level $[10,21,23]$. However, the studies conducted for the development of energy concepts at different levels of education at the high school level in Turkey are known to be quite a few. This study will provide information about both developments of concepts and also of misconceptions. In this way, the development of the energy concept and misconceptions at the high school level will be revealed. Thus it is thought that developmental data to be examined will contribute to concept teaching. The basic problem status of this study is accordingly to determine how high school students at different levels perceive the energy and related concepts. And the sub-problems are;

1. How do high school students at different levels perceive energy concept?

2. What kind of energy can high school students at different levels define?

3. How should high school students at different levels classify energy types?

4. How high school students at different levels interpret conservation of energy?

\section{Materials and Method}

The developmental research method of descriptive research design has been used to determine information about the energy concept of students at different levels. In the developmental research method in which a fact or an incident examined change or development in time is stressed, instead of studying the same topic or sampling for a long time, studies conducted equivalent samplings are expressed as cross-grade studies [24]. In this respect, the study is a cross-grade study within the developmental research method.

\subsection{Sampling}

The sampling of the study is composed of students, whose ages are ranging between 15 and 17, of a high school chosen randomly in Gumushane, Turkey. The sampling group has been selected from the 9th, 10th and 11 th grade students. 57 students of the 9 th grade, 94 ones of the 10th grade and 22 ones of the 11th grade have participated in the study. Thus, 173 students in total have participated in the study.

\subsection{Data Collection Tool}

A four-item questionnaire consisting of open-ended questions developed by the researcher has been used as a data collection tool in the study. The questionnaire includes questions about the definition of energy concept, types, definition and examples of energy and the conservation of energy. It is aimed to investigate misconceptions and knowledge levels of the students with these questions. Having created questionnaire form, content validity was obtained by consulting two experienced physics teachers.

\subsection{Analysis of the Data}

In the first stage of the study, the answers given by the students have been evaluated using the assessment used by Abraham, Williamson, and Wetsbrook [25] and Baskan [26]. The assessment has been examined under four categories. The answers have been collected under correct, partially correct, wrong and unanswered categories. The correct answers include acknowledged descriptions which overlap with scientific facts. The partially correct answers are those containing a section of the correct answer or answers containing wrong or inappropriate answers with a section of the correct answer. The wrong answers cover inappropriate statements that are not related to scientific facts and are not used for explaining the question. Unanswered ones include no description about the question. In the second stage of the study, similar answers are grouped under the same category by grouping partially correct and wrong answers separately and each category is frequent and the data have been converted into tables.

\section{Results}

In this section, the findings have been examined in headlines of energy concept, energy types, classifying energy types and conservation of energy.

\subsection{The Concept of Energy}

When the Table 1 is examined, it is seen that almost half 
of the 11th grade students have explained the concept of energy correctly. 12 students of the 10th grade and 7 students of the 9 th grade have correct answers. The rate of partially correct answers of the 11th grade students is higher than two other grades again. The highest rate in the wrong category belongs to the 10th grade students. 17 students of the 9th grade, 21 students of the 10th grade and 8 students of the 11th grade have given wrong answers. While all students of the 11th grade have answered this question, 6 students of the 9th grade, 11 students of the 10 th grade have not answered this question.

"It is the power emerging in forms of heat and light in the matter" in the partially correct category has been expressed by the students at all levels. "It is movement of an object after applying force" and "it is the thing which is necessary to do the work" are stated by only the 9th grade and the 10 th grade students. When the wrong answer category is examined, it is seen that "it emerges in human body thanks to foods" and "it is the power" have been expressed by students at all levels again. An example in this category is "Energy is an influence that is not seen on living creatures. As humans take a rest and eat, they have this influence. It is effective in scientific activities besides daily life. Some energy is created by people while some of them emerge with food in human body." (the 9th grade). Another student in the same category has answered this question "It is composed of foods that all living creatures eat and fragmentation of foods in our body" (10th grade). A student in power category has said "It is the power which is transferred from somewhere to somewhere and is not lost" (11th grade). Besides, there are situations emerging with movement, pushing and pulling, the feature existing in the basic unit of matter, energy forms or types, work and unrelated answer categories. "I think we do not learn energy in the class" (9th grade) can be shown as an example from unrelated answers category.

Table 1. Students' answers about energy definition

\begin{tabular}{|c|c|c|c|c|c|c|c|}
\hline \multirow[t]{2}{*}{ Category } & \multirow[t]{2}{*}{ Answers of the students } & \multicolumn{2}{|c|}{ 9th grade } & \multicolumn{2}{|c|}{ 10th grade } & \multicolumn{2}{|c|}{ 11th grade } \\
\hline & & $\mathrm{f}$ & $\%$ & $\mathrm{f}$ & $\%$ & $\mathrm{f}$ & $\%$ \\
\hline Correct & It is the ability to do work & 7 & 12 & 12 & 13 & 9 & 41 \\
\hline \multirow{3}{*}{$\begin{array}{c}\text { Partially } \\
\text { Correct }\end{array}$} & It is power emerging in forms of heat, light, etc. existing in the matter & 7 & 12 & 6 & 6 & 5 & 23 \\
\hline & It is movement of an object after applying force & 4 & 7 & 1 & 1 & - & - \\
\hline & It is the thing which is necessary to do the work & 1 & 2 & 6 & 6 & - & - \\
\hline \multirow{9}{*}{ Wrong } & It is the movement done & 7 & 12 & 13 & 14 & - & - \\
\hline & It emerges in human body thanks to foods & 8 & 14 & 4 & 4 & 2 & 9 \\
\hline & It is the power & 7 & 12 & 4 & 4 & 4 & 18 \\
\hline & It is the situation emerging with pushing and pulling & 2 & 4 & - & - & - & - \\
\hline & It is the feature existing in the basic unit of matter & 3 & 5 & 4 & 4 & - & - \\
\hline & Energy forms/types & - & - & 17 & 18 & - & - \\
\hline & It is the work & - & - & 1 & 1 & - & - \\
\hline & Unrelated & 4 & 7 & 15 & 16 & 2 & 9 \\
\hline & Unanswered & 7 & 12 & 11 & 12 & - & - \\
\hline
\end{tabular}




\subsection{Energy Types}

In this category, none of the students has answered the question about energy types correctly. On the other hand, 45 students of the 9th grade, 54 students of the 10th grade and 10 students of the 11th grade could write and explain some of energy types. 17 students of the 9th grade, 21 students of the 10th grade and 8 students of the 11th grade have given wrong answers. While 1 student of the 9th grade and 4 students of the 10th grade have not answered this question, all of the students of the 11th grade have answered this question.
As seen in the Table 2, when answers given by the students are evaluated, potential and kinetic energy are the most common answers stated by the students as energy types. When other correct answers are examined, mechanical, electrical, chemical, nuclear, sound and thermal energy types have been obtained. The wrong answers given for energy types are heat, luminous, solar, hydro-electric, wind, friction, natural gas, human body, water and fossil. The energy types, some explanations and examples for them stated by the students are shown in the Table 3 .

Table 2. Students' answers about energy types

\begin{tabular}{|c|c|c|c|c|c|c|}
\hline \multirow[t]{2}{*}{ Categories } & \multicolumn{2}{|c|}{ 9th grade } & \multicolumn{2}{|c|}{ 10th grade } & \multicolumn{2}{|c|}{ 11th grade } \\
\hline & $\mathrm{f}$ & $\%$ & $f$ & $\%$ & f & $\%$ \\
\hline Kinetic & 53 & 93 & 51 & 54 & 12 & 54 \\
\hline Potential & 48 & 84 & 45 & 48 & 10 & 45 \\
\hline Mechanical & 20 & 35 & 18 & 19 & 4 & 18 \\
\hline Electrical & 20 & 35 & 18 & 19 & 7 & 32 \\
\hline Chemical & 2 & 4 & 11 & 12 & 8 & 36 \\
\hline Nuclear & 7 & 12 & 14 & 15 & 9 & 41 \\
\hline Sound & - & - & 8 & 8 & 5 & 23 \\
\hline Thermal & - & - & 16 & 17 & 2 & 9 \\
\hline Luminous & - & - & 22 & 23 & 6 & 27 \\
\hline Heat & 6 & 11 & 15 & 16 & 9 & 41 \\
\hline Solar & 24 & 42 & 36 & 38 & 11 & 50 \\
\hline Hydro-electric & 8 & 14 & 21 & 22 & 2 & 9 \\
\hline Wind & 18 & 32 & 33 & 35 & 8 & 36 \\
\hline Friction & 2 & 4 & 7 & 7 & - & - \\
\hline Wave & - & - & 2 & 2 & - & - \\
\hline Natural gas & - & - & - & - & 2 & 9 \\
\hline Human body & 3 & 5 & - & - & - & - \\
\hline Water & - & - & - & - & 2 & 9 \\
\hline Fossil & 1 & 2 & - & - & 1 & 4 \\
\hline
\end{tabular}

*Those written in italic font are wrong

Table 3. Some energy types, explanations and examples given by the students as an answer

\begin{tabular}{|c|c|c|c|}
\hline Energy type & Explanation & Example & Grade \\
\hline Electrical energy & $\begin{array}{c}\text { A current passing through a wire } \\
\text { produce energy }\end{array}$ & Lamp & 10 th grade (C) \\
\hline Nuclear energy & It occurs in result of fusion fission & Separation of radioactive elements into atoms & 10 th grade (C) \\
\hline Chemical energy & Chemical reaction of matters & Burning of a paper & 11 th grade (D) \\
\hline Heat energy & It is temperature of a matter & Stove & 9 th grade (F) \\
\hline Friction energy & $\begin{array}{c}\text { Energy when we rub object to } \\
\text { something }\end{array}$ & Rubbing one's hands each other & 9 th grade (F) \\
\hline Luminous energy & It provides lightening environment & Bulb & 10 th grade (F) \\
\hline Solar energy & Energy obtained through the sun & Solar panels & 10 th grade (F) \\
\hline Wind energy & Spinning windmill & Windmill & 11 th grade (F) \\
\hline
\end{tabular}

(C) stands for correct answers (F) stands for false ones. 


\subsection{Classifying Energy Types}

When the question about classifying energy types is examined, it is seen that while 21 students of the 9th grade and 4 students of the 10th grade have given correct answers, none of the students of 11th grade has answered this question correctly. 13 students of the 9 th grade, 15 students of the 10th grade and 5 students of the 11th grade have given partially correct answers. 17 students of the 9 th grade, 21 students of the 10th grade and 8 students of the 11th grade have given wrong answers. 10 students of the 9th grade, 42 students of the 10th grade and 4 students of the 11 th grade have not answered this question.

When examining energy type classifications made by the students in the Table 4, it is seen that most of the students know energy types and include energy forms to classification. Furthermore, it is revealed that some students classify energy types according to subcategories. The students have made groupings by expressing renewable and non-renewable energy types and natural and artificial energy types.

\subsection{Conservation of Energy}

The students of the 11th grade have given correct answer to the question about conservation of energy more than other students. 17 students of the 9th grade, 21 students of the 10th grade and 8 students of the 11th grade have given wrong answers. 6 students of the 9th grade, 7 students of the 10th grade and 2 students of the 11th grade have given partially correct answers. 17 students of the 9th grade, 21 students of the 10th grade and 8 students of the 11th grade have given wrong answers. 34 students of the 9th grade, 65 students of the 10th grade and 6 students of the 11th grade have not answered this question.

According to partially correct answers in the Table 5, the students have stated that energy cannot be created out of nothing, non-existent energy can be transformed from one type to another and for this an isolated system is needed. For example, an answer of a student in this category and stating energy is not existing and can be transferred from a type to another one is "Energy neither can be destroyed from existing nor can be existed from nothing but energy type can be transferred. For instance, during dynamite bursting, the chemical energy can be transformed into kinetic energy. It is impossible for perpetual motion machine to work as a matter of the law of conservation of energy" (11th grade). When wrong answers are examined, it is seen that students state conservation of energy can be provided with energy saving, power plants and frictionless systems. The answer of a student claiming that conservation of energy is possible with energy saving: "If we do not waste energy, we conserve it" (9th grade). On the other hand, the answer of a student saying that energy can be conserved with power plants and manufacturing plants: "We conserve wind with wind mills and use it when it is necessary. We collect energy thanks to solar panels, accumulate it and use it when it is necessary" (10th grade). In addition, while some students believe energy cannot be conserved under any circumstances, some have given unrelated answers. One of the unrelated answers is "There are many types of energy and we should use beneficial ones" (10th grade).

Table 4. Students' answers about classifying energy types

\begin{tabular}{|c|c|c|c|c|c|c|}
\hline & \multicolumn{2}{|c|}{9 th grade } & \multicolumn{2}{c|}{10 th grade } & \multicolumn{2}{c|}{11 th grade } \\
\hline & $\mathrm{f}$ & $\%$ & $\mathrm{f}$ & $\%$ & $\mathrm{f}$ & $\%$ \\
\hline Kinetic-potential & 21 & 36 & 4 & 4 & - & - \\
\hline Energy types and energy forms & 13 & 23 & 15 & 16 & 5 & 23 \\
\hline Energy types & 7 & 12 & 11 & 12 & 4 & 18 \\
\hline Renewable- nonrenewable & 5 & 9 & 14 & 15 & 4 & 18 \\
\hline Natural- artificial & 1 & 2 & 8 & 8 & 5 & 23 \\
\hline Unanswered & 10 & 18 & 42 & 45 & 4 & 18 \\
\hline
\end{tabular}

Table 5. Students' answers about conservation of energy

\begin{tabular}{|c|c|c|c|c|c|c|c|}
\hline \multirow[t]{2}{*}{ Categories } & \multirow[t]{2}{*}{ Answers of the students } & \multicolumn{2}{|c|}{ 9th grade } & \multicolumn{2}{|c|}{ 10th grade } & \multicolumn{2}{|c|}{ 11th grade } \\
\hline & & $\mathrm{f}$ & $\%$ & $\mathrm{f}$ & $\%$ & $\mathrm{f}$ & $\%$ \\
\hline Correct & Total energy does not change in an isolated system & - & - & 6 & 6 & 6 & 27 \\
\hline \multirow{3}{*}{$\begin{array}{l}\text { Partially } \\
\text { Correct }\end{array}$} & Energy cannot be created out of nothing & 5 & 9 & - & - & - & - \\
\hline & Non-existent energy can be transformed from one type to another & - & - & 2 & 2 & 2 & 9 \\
\hline & An isolated system is needed & 1 & 2 & - & - & - & - \\
\hline \multirow{5}{*}{ Wrong } & It is preserved with energy saving & 5 & 9 & 6 & 6 & 6 & 27 \\
\hline & It is conserved in power plants & 4 & 7 & 5 & 5 & - & - \\
\hline & It is conserved in frictionless systems & 2 & 4 & - & - & - & - \\
\hline & Energy is not conserved & - & - & & & 2 & 9 \\
\hline & Unrelated & 6 & 11 & 10 & 11 & - & - \\
\hline Unanswered & Unanswered & 34 & 58 & 65 & 70 & 6 & 27 \\
\hline
\end{tabular}




\section{Discussion and Conclusions}

The teaching of energy is one of the main objectives of science courses in schools [27]. The fact that energy includes qualitative and quantitative data and abstract concepts makes it difficult to understand energy concept. For this reason, it is inevitable to face various difficulties during energy education in schools. Taking into consideration that the first phase to prevent these hardships is to determine existing ones and specify development of them according to different grade levels, it is aimed to determine misconceptions of energy and related concepts developmentally depending on different grades in this study.

When the data obtained developmentally from the students are examined, similar misconceptions of the students at different levels have revealed. As the level progresses, the number of students who respond correctly or partially correct is increasing too. Some reasons of this situation are that misconceptions decrease as a result of learning physics concepts in progressing classes and similar concepts are taught in different lessons. On the other hand, although the energy concept exits in different lesson contents, it is not related by teachers and course curricula [16]. This relation is thought to emerge from the fact that students gradually associate between concepts. When the situation of different grades is considered in terms of energy forms and types, although the students of the 11th grade have more information about energy types, the students of the 9th grade have given more correct answers to the related questions. When the curriculum of the students has been examined, it is seen that the energy concept is planned to be introduced in the $9^{\text {th }}$ grade [28]. While some knowledge has become permanent, some of them can be forgotten. Thus it is not surprising that the students of the $9^{\text {th }}$ grade are more successful in certain subjects than other grades.

The common difficulty in defining energy is that they use preparatory concepts about energy instead of the energy. The students express related concepts with energy such as work, power, movement, pushing and pulling as energy. It is a result of that abstract concepts related to the abstract energy concept such as work, power, pushing and pulling are not fully perceived. The main reason for this is that before the students understand preparatory energy concepts they try to comprehend the energy concept $[1,5$, 29]. Furthermore, the energy concept is taught after physical notions such as work and power. Not to learn these concepts makes difficult learning the energy concept thus the students cannot define this concept clearly and they use related concept instead of it.

Another misconception expressed by the students at every level is that energy exists in the living body and is formed thanks to foods. Similar misconception is seen from the students at primary school level to those in the university $[1,15,19,20,30]$. This kind of misconception is thought to be seen due to the fact that it is taught that the food is burned in cells and converted to ATP in the biology lesson [15]. Moreover, it is believed that the fact that expression of "being energetic" is used by the students in daily life supports this misconception [1]. Besides, another misconception stated by students is that the energy is only associated with moving objects. This misconception, also expressed by different researchers, is the result of the fact that the students do not have knowledge of the existence of energy burden in the nature $[10,31]$. As a result, it is revealed that high school education has improved definition of energy and helped to reduce misconception, interaction of different lessons has not been stressed and the biggest obstacle to define the energy is the fact that the students are taught energy concept before the concepts related to the energy.

Most students have indicated the potential and kinetic energy while writing energy types and expressing energy forms. It is known that the mechanical topics are the most prevalent topics in science subjects [31]. That is to say, emphasizing the potential and kinetic energy issues in the schools shows that these subjects are easily structured in the mind of the individuals. When examining the high school curricula, the energy unit is only available as a unit within the physics course, and mechanical energy issues take up considerable space in its content [32]. The inability of the students to express other energy types stems from the fact that they have no background information in the subjects in question [33]. For this reason, it is not surprising that students stress kinetic and potential energy. It is thought that another reason of the fact that students do not mention other energy types is that they cannot establish any relationship between different types of energy [34]. Moreover, even teacher candidates have considerable difficulties in understanding the relationship between the types of energy [15]. In the similar studies, that students define heat, light, electricity, potential, and kinetic energy as energy sources can be attributed to the fact that these subjects are not systematically associated with the content of school courses. [35]. Since different types of energy are explained without being related to each other, they are understood to be disconnected and irrelevant and the types of energy cannot be fully structured in the minds of individuals [29]. In addition, it is thought that associating the energy types with previously learned concepts and relating them to new knowledge influence learning positively [15]. It is known that the classification of energy types and energy forms cannot be completely distinguished even in studies carried out at primary school level [5].

It is seen that the students often give example for classifying energy types as renewable and non-renewable energy sources, while they classify energy sources according to renewable and non-renewable energy sources. There are studies in the literature that support students' lack of knowledge about renewable and non-renewable energy sources $[35,36]$. This suggests that although the students are familiar with various information about renewable and 
non-renewable energy sources, they cannot fully distinguish between these concepts. It is believed that this is due to the fact that the students do not get enough information about renewable energy at an early age [36]. As a result, confusion emerges while making a classification according to energy sources and types. Furthermore, it is seen that classifying energy types are considered in natural and artificial categories. The students express natural and artificial energy sources in this classification. Similar misconceptions are seen at primary school level [36]. The fact that this misconception is also seen at the high school level can be shown as proof that similar misconceptions are difficult to rectify in later ages.

The fact that the questions about energy conversation have not been answered by most of the students shows that they don't have enough information about this topic. As a matter of fact, when the curricula are examined, it is seen that energy transformations and mechanical energy are the most emphasized subjects [32]. Likewise, Kurnaz [37] has revealed the lack of the first-year university students about energy conservation and has found that they are unable to express that while energy is transforming from a form to another it is conserved in an isolated system. It is known that even prospective teachers have found that they cannot fully explain the energy transformations and they focus only on kinetic and potential energy transformations in energy transformations [38]. However, in contrast to this case, Gurdal, Sahin and Bayram [15] stated that the prospective teachers know that the energy could be transformed from one form in which energy is not lost to another. Oztas [39] stated that high school students could not apply issues about energy transformation in matters to different disciplines. This may be due to the fact that energy conservation remains as a topic only in physics course and cannot be explained by examples in different fields. As a matter of fact, the students involved in the current study have often associated energy conservation with power generating plants and have often expressed their opinions on energy saving. As a result, it has brought with it a contradiction in concepts about the saving use of energy with the energy conservation law for students. In studies to be conducted accordingly, stressing effective usage of energy after teaching energy concepts and laws is thought to reduce this misconception.

As a result, taking into consideration the importance of progressivity in teaching energy, the students should be firstly taught the concepts, then the laws and the theories. New concepts should not be taught before basic concepts are taught. Therefore, the students should be taught new concepts, laws or theories following basic concepts. In addition, the students perceiving the relationship between concepts will be able to learn new concepts more easily. For this reason, concept networks, concept maps and conceptual change texts, which are frequently used in relation between concepts, are considered to cover this shortcoming. Since these applications have significant influences on preventing misconceptions of the students and developing structure-based learning [17]. Thus the curricula should be planned by taking alternative methods mentioned above into consideration to arrange suitable courses for learning materials in question. The fact that the students express kinetic and potential energy concepts when energy types and forms are in question can be shown as a result of that other energy types are not stressed enough. The energy types of different disciplines in question have more related topics. Therefore, teaching energy concepts and relationship between them in chemistry and biology courses as well as physics course may be beneficial so that the students can strengthen relationships between concepts.

\section{REFERENCES}

[1] D. M. Watts. Some alternative views of energy. Physics Education, Vol. 18, 213-217. 1983.

[2] R. Osborne, P. Freyberg, Children's Science, In R. Osborne and P. Freyberg (Eds.) Learning in Science: The implications of children's science, 5-14, Heinemann, Hong Kong, 1985.

[3] M. A. Kurnaz, M. Çalık. Using different conceptual change methods embedded within 5E model: a sample teaching for heat and temperature. Journal of Physics Teacher Education. Vol. 5, No. 1, 3-10. 2008.

[4] H.Çelik. An examination of cross sectional change in student's metaphorical perceptions towards heat, temperature and energy concepts. International Journal of Education in Mathematics, Science and Technology, Vol. 4, No. 3, 229-245. 2016.

[5] K. Yürümezoğlu, S. Ayaz, A. Çökelez. Grade 7-9 Students' Perceptions of Energy and Related Concepts. Necatibey Faculty of Education Electronic Journal of Science and Mathematics Education, Vol. 3, No. 2, 52-73. 2009.

[6] D. Palmer. Exploring the link between students' scientific and nonscientific conceptions. Science Education, Vol. 83, 639-653. 1999.

[7] P.L. Schulte. Preservice elementary teachers' alternative conceptions in science and attitudes towards teaching science. Unpublished Phd thesis, University of New Orleans, New Orleans. 2001.

[8] Ö. Yılmaz, C. Tekkaya, Ö. Geban, Y. Özden. Lise 1. sınıf öğrencilerinin hücre bölünmesi ünitesindeki kavram yanılgılarının tespiti ve giderilmesi. Paper presented at the III. Ulusal Fen Bilimleri Eğitimi Sempozyumu, Karadeniz Teknik Üniversitesi, Trabzon. 1998.

[9] R. Yağbasan, Ç. Gülçiçek. Fen öğretiminde kavram yanılgılarının karakteristiklerinin tanımlanması. Journal of Pamukkale University Education Faculty, Vol. 1, No. 13, 102-119. 2003.

[10] R. Trumper. A longitudinal study of physics students' conceptions on energy in pre-service training for high 
school teachers. Journal of Science Education Technology, Vol. 7, No. 4, 311-318. 1998.

[11] A. Sağlam-Arslan, and Kurnaz, M. A. Prospective physics teachers' level of understanding energy, power and force concepts. Asia-Pacific Forum on Science Learning and Teaching, Vol.10 No.1, Article 6. 2009

[12] M. A. Kurnaz. Enerji konusunda model tabanlı öğrenme yaklaşımına göre tasarlanan öğrenme ortamlarının zihinsel model gelişimine etkisi. Unpublished doctoral dissertation, Karadeniz Technical University, Trabzon. 2011.

[13] M. A. Kurnaz, A. Sağlam-Arslan. Model tabanlı öğrenme yaklaşımını temel alan öğrenme ortamının öğrencilerin enerji kavramını anlama düzeylerine etkisi. E-international journal of educational research, Vol. 2 No. 2, 1-16. 2011.

[14] R. Gunstone, R. White, P. Fensham. Developments in style and purpose of research on the learning of science. Journal of Research in Science Teaching, Vol. 25, 513-530. 1988.

[15] A. Gürdal, F. Şahin, H. Bayram. İlköğretim öğretmen adaylarının enerji konusunda bütünlüğü sağlama ve ilişki kurma düzeyleri üzerine bir araștırma. Journal of Buca Faculty of Education, Vol. 10, 382-395. 1999.

[16] G. Aydın, A. G. Balım. Yapılandırmacı yaklaşıma göre modellendirilmiş disiplinler arası uygulama: enerji konularının öğretimi. Ankara University, Journal of Faculty of Educational Sciences, Vol.38, No. 2, 145-166. 2005.

[17] M. Küçük, S. Çepni, M. Gökdere. Turkish primary school students' alternative conceptions about work, power and energy. Journal of Physics Teacher Education, Vol. 3, No. 2, 22-28. 2005.

[18] M. Konuk, S. Kılıç. Fen Bilimleri Öğrencilerinde Bitki ve Hayvanlardaki Enerji Kaynağı Konusundaki Kavram Yanılgilar1. Paper presented at the III. Ulusal Fen Bilimleri Eğitimi Sempozyumu, Ankara. 1999.

[19] C. Kruger. Some primary teacher ideas about energy. Physics Education, Vol. 25, 86-91. 1990.

[20] C. Kruger, D. Palacio, M. Summers. Surveys of English primary school teachers' conceptions of force, energy and materials. Science Education, Vol. 76, No. 4, 339- 351. 1992.

[21] A. Sağlam Arslan. Cross-grade comparison of students 'understanding of energy concepts. Journal of Science Education and Technology, Vol. 19, No. 3, 303-313. 2009.

[22] M. Çalık, A. Ayas. A cross-age study on the understanding of chemical solutions and their components. International Education Journal, Vol. 1, 30-41. 2005.

[23] U. Töman, O.S. Çimer. Enerji kavramının farklı öğrenim seviyelerinde öğrenilme durumunun araştırılması. Bayburt University Journal of Faculty of Education, Vol. 6, 27-39. 2011.

[24] S. Çepni. Araştırma ve proje çalışmalarına giriş, 3th edition, Celepler Matbaacılık. Trabzon, 2007.

[25] M. R. Abraham, V. M. Williamson, S. L. Wetsbrook, A cross-age study of the understanding of five chemistry concepts. Journal of Research in Science Teaching, Vol. 31,
No.2, 147-165. 1994.

[26] Z., Başkan. Doğrusal ve düzlemde hareket ünitelerinin matematiksel modelleme kullanılarak öğretiminin öğretmen adaylarının öğrenmelerine etkileri, Doctoral Thesis. Karadeniz Technical University, Trabzon. 2011.

[27] A. Göçük, F. Şahin. Probleme dayalı öğrenme yaklaşımının 5. Sınıf öğrencilerinin enerji okuryazarlıkları üzerine etkisi. Journal of Human Sciences, Vol. 13, No. 2, 3446- 3468. 2006.

[28] MEB (2013). Fizik Öğretim Programı, http://mebk12.meb.gov.tr/meb iys dosyalar/31/01/972850 /dosyalar/2013 07/05032334 fizik 912.pdf, ET: 14.02.2017.

[29] T. Güneș, F. Taştan Akdağ. Determination of perceptions of science high school students on energy and their levels of interdiciplinary association. International Journal of Social Sciences and Education Research, Vol. 2, No. 2, 774-787. 2016.

[30] N. Hırça, M. Çalık, F. Akdeniz. Investigating grade 8 students' conceptions of 'energy' and related concepts. Journal of Turkish Science Education, Vol. 5, No. 1, 75-87. 2008.

[31] G. Ünal Çoban, H. Aktamış, Ö. Ergin, İlköğretim sekizinci sınıf öğrencilerinin enerjiyle ilgili görüşleri. Kastamonu Education Journal, Vol. 15, No. 1, 175-184. 2007.

[32] MEB (2017). Physics Teaching Program, online available from

http://mufredat.meb.gov.tr/ProgramDetay.aspx?PID=174

[33] M. Else. Transferring, not transforming energy. School Science Review, Vol. 69, 427- 437. 1988.

[34] S. Aydoğan, B. Güneş, Ç. Gülçiçek. Isı ve sıcaklık konusundaki kavram yanılgiları. Gazi University Journal of Gazi Educational Faculty, Vol. 23, No. 2, 111-124. 2003.

[35] U. Töman, S. Çimer. Enerji kaynakları ve enerji depolanması kavramlarının farklı öğrenim seviyelerinde öğrenilme durumunun araştırılması. Dicle University Journal of Ziya Gökalp Faculty of Education, Vol. 21, 47-68. 2013.

[36] E. Benzer, B. Karadeniz-Bayrak, C. Dilek-Eren, A. Gürdal. İlköğretim öğrencilerinin enerji ve enerji kaynaklarıyla ilgili bilgi ve görüşleri: Eski ve yeni öğretim programlarının karşılaştırılmasıyla. The Journal of Academic Social Science Studies, Vol. 25, No. 1, 285-298. 2014.

[37] M. A. Kurnaz. Üniversite 1. Sinıf seviyesinde enerji kavramının öğrenim durumlarının analizi. Unpublished Master's Disseration, Karadeniz Technical University, Trabzon. 2007.

[38] V. N. Kırtak Ad, N. Demirci. Öğretmen adaylarının çevre sorunlarını bilim dalları ve termodinamik yasaları ile ilișkilendirme düzeyleri. Ahi Evran University Journal of Kırşehir Education Faculty, Vol. 13, No. 3, 19-46. 2012.

[39] F. Öztaş. Lise 9. sınıf öğrencilerinin madde döngüsü ve enerji akışı ile ilgili görüşlerinin saptanmasına yönelik bir araştırma. Kastamonu Education Journal. Vol. 13, No. 2, 381-390. 2005 